\title{
Wind Profile Characteristics and Energy Potential Assessment for Electricity Generation at the Karaburun Peninsula, Albania
}

\author{
Eduart Serdari, Pëllumb Berberi, Valbona Muda, Urim Buzra, Driada Mitrushi, and Daniela Halili
}

\begin{abstract}
Wind energy is expected to have a successful future and an essential role in many countries as well as Albania. The aim of this study is to present wind profile characteristics and electricity generation potential from wind for the Karaburun peninsula in southwestern part of Albania $\left(40.39^{\circ} \mathrm{N} ; 19.34^{\circ} \mathrm{E}\right.$; altitude $88 \mathrm{~m}$; air density $1.211 \mathrm{~kg} / \mathrm{m}^{3}$ ). A long term data, consisting of thirty four years (1981 to 2014) of hourly mean wind data, was adopted and analyzed. Mean wind power based on measured data and Weibull distribution function have been studied. Based on two methods it was found that Weibull distribution was suitable for this study. Numerical values of the shape and scale parameters for the Karaburun peninsula varied over a certain range. The two parameters of the Weibull were found to lie between $1.56 \leq \mathrm{k} \leq 1.77$ and $6.26 \leq \mathrm{c} \leq 7.84 \mathrm{~m} / \mathrm{s}$. The annual mean wind speed ranged between $6.33 \mathrm{~m} / \mathrm{s}$ and $7.00 \mathrm{~m} / \mathrm{s}$ at $50 \mathrm{~m}$ height. In addition, three real turbine models were assessed for the site's wind profile, with results suggesting economic viability.
\end{abstract}

Index Terms-Energy, weibull distribution, wind direction, wind profile.

\section{INTRODUCTION}

The demand for electricity is growing rapidly in Albania. Wind energy appears as a good solution to cope with a great part of this rapidly growth energy demand. Albania as a result of its geographical situation has a high development potential to exploit wind sources. Actually only hydropower makes a major contribution to the electricity consumption in the country. Until now there are no wind energy producers in Albania. However, two important projects, respectively 500 MW and 200 MW in Vlora (Karaburun) and in Kavaja (Kryevidh), are under consideration [1].

The present work is focused on the thirty four years metrological data of the Karaburun peninsula. The selected site is the largest peninsula of Albania, located near the city of Vlora, southwestern Albania, where the Adriatic Sea meets the Ionian Sea [2].

The purpose of this paper was therefore to classify the wind profile characteristics of the meteorological site for wind turbine application. It was also intended to determine the financial possibility of employing wind turbines to produce electricity at the site. Fig. 1 gives the map of this site. The

Manuscript received April 19, 2016; revised June 6, 2016

The auhors are with Department of Engineering Physics, Faculty of Engineering Mathematics and Engineering Physics, Polytechnic University of Tirana, Tirana, Albania (e-mail: eduartserdari@ymail.com, pellumb.berberi@gmail.com,vmuda@hotmail.com,rimibuzra@yahoo.com driadamitrushi@yahoo.com,topciudaniela@yahoo.com). study has completed the of yearly and monthly mean wind resource measurements averaged from daily readings to statistically analyze the wind resource potential of Karaburun for the power generation.

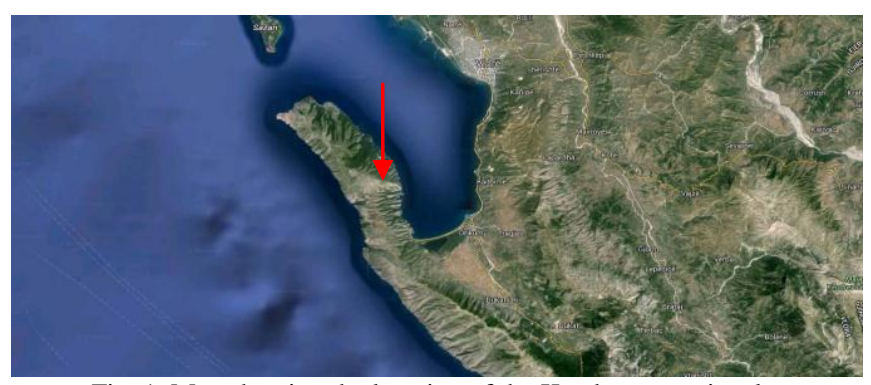

Fig. 1. Map showing the location of the Karaburun peninsula.

\section{MATERIALS AND METHODS}

Thirty four years (1981 to 2014) of hourly wind speed records for the Karaburun peninsula $\left(40.39^{\circ} \mathrm{N}\right.$; $19.34^{\circ} \mathrm{E}$; altitude $88 \mathrm{~m}$; air density $1.211 \mathrm{~kg} / \mathrm{m} 3$ ) were adopted in this study. The data were recorded continuously at a height of 50 m. Fig. 2 gives the whole data spread across this period considered. Fig. 3 gives the 34-year monthly average wind speeds and the yearly average sharing for the period.

\section{A. Monthly Average Wind Speed, Standard Deviation and Wind Rose}

Monthly average wind speed and standard deviation were obtained, as follows:

$$
\begin{gathered}
v_{m}=\frac{1}{n} \sum_{i=1}^{n} v_{i} \\
\sigma=\sqrt{\frac{1}{n-1} \sum_{i=1}^{n}\left(v_{i}-v_{m}\right)^{2}}
\end{gathered}
$$

where, $\sigma$ is the standard deviation, $n$ the number of years considered, $v_{i}$ is the wind speed value of each months $(\mathrm{m} / \mathrm{s})$, $v_{m}$ is the average wind speed $(\mathrm{m} / \mathrm{s})$ [3].

Moreover, to conduct wind energy research it is significant to determine wind direction. The wind direction is illustrated in polar diagrams and it is measured in clockwise direction. The cycle is divided in 16 sectors, each of 22.5 degree [4]. Fig. 4 shows the wind directions expressed with the wind rose.

\section{B. Wind Speed Probability Distribution}

The Weibull probability distribution function (PDF) was employed to characterize the wind profile of the selected site since it is more suitable for statistical analysis. This is because 
the Weibull PDF has been proved to be adequate and accurate for numerous statistical distributions. The $\operatorname{PDF} f(v)$ and the corresponding cumulative density function (CDF) $F(v)$ were obtained refer to (3) and (4) [5].

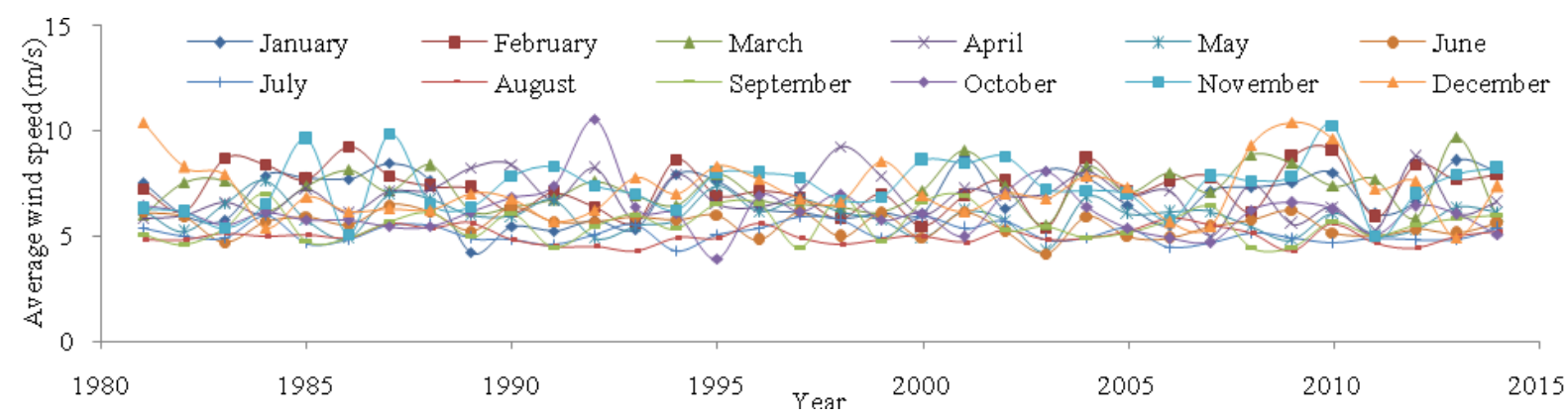

Fig. 2. Thirty-four year average of wind speeds at height $50 \mathrm{~m}$ over the ground in Karburuni peninsula for each month of each year of the period from the year 1981to 2014.

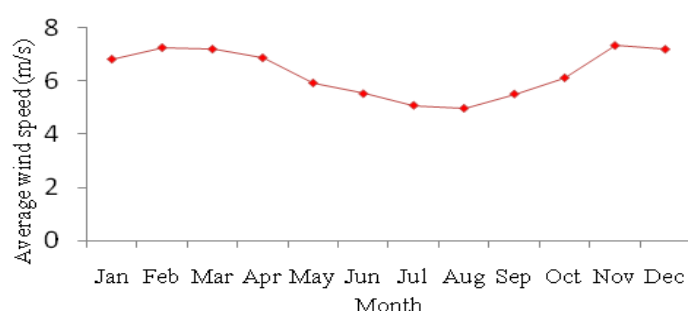

a)

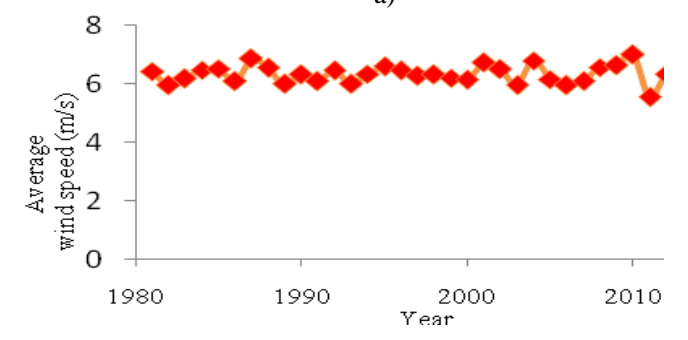

b)

Fig. 3. Thirty-four year average wind speeds at height $50 \mathrm{~m}$ over the ground in the Karburuni peninsula, a) monthly average and b) yearly average wind speed.

$$
\begin{gathered}
f(v)=\left(\frac{k}{c}\right)\left(\frac{v}{c}\right)^{k-1} \exp \left[-\left(\frac{v}{c}\right)^{k}\right] \\
F(v)=1-\exp \left[-\left(\frac{v}{c}\right)^{k}\right]
\end{gathered}
$$

where, $k$ is shape parameter, $c(\mathrm{~m} / \mathrm{s})$ is scale parameter and $v$ is wind speed.

There are several methods to identify the parameters of Weibull PDF. The most suitable and accurate according to many research papers is Maximum Likelihood Method [2]-[5]. Based on two parameters $(k$ and $c)$, the mean wind speed and standard deviation were determined, as follows:

$$
\begin{gathered}
v_{m}=c \Gamma\left(1+\frac{1}{k}\right) \\
\sigma=\sqrt{c^{2}\left\{\Gamma\left(1+\frac{2}{k}\right)-\left[\Gamma\left(1+\frac{1}{k}\right)\right]^{2}\right\}}
\end{gathered}
$$

where, $\Gamma(x)$ is the gamma function of $(x)$.

\section{Wind Power Density}

The available power $P(v)$ in the wind flowing through a rotor blade with swept area A $\left(\mathrm{m}^{2}\right)$, is obtained as follow:

$$
P(v)=\frac{1}{2} \rho A v_{m}^{3}
$$

The wind power per unit area $p(v)$ is estimated based on the Weibull PDF, as follow [2]-[5]:

$$
p(v)=\frac{P(v)}{A}=\frac{1}{2} \rho c^{3} \Gamma\left(1+\frac{3}{k}\right)
$$

\section{The Electrical Power Output from a Wind Turbine}

The amount of wind power that can be produced from a practical wind turbine applied at the site was simulated refer to (9). The average power output $\left(P_{e, \text { ave }}\right)$ from a wind turbine corresponding to the total energy production and related to the total income was evaluated, as follow [2]-[7]:

$$
\begin{aligned}
& P_{e}=\left\{\begin{array}{cc}
0 & \left(v<v_{c}\right) \\
P_{e R} \frac{v^{k}-v^{c}}{v_{R}^{k}-v_{c}^{k}} & v_{c} \leq v \leq v_{R} \\
P_{e R} & v_{R} \leq v \leq v_{F} \\
0 & v>v_{F}
\end{array}\right. \\
& P_{e, a v e}=P_{e R}\left\{\frac{e^{-\left(v_{c} / c\right)^{k}}-e^{-\left(v_{R} / c\right)^{k}}}{\left(v_{R} / c\right)^{k}-\left(v_{c} / c\right)^{k}}-e^{-\left(v_{F} / c\right)^{k}}\right\}
\end{aligned}
$$

The capacity factor (CF) of generation is evaluated as follow:

$$
C F=\frac{P_{e, a v e}}{P_{e R}}
$$

where, $P_{e R}=$ rated electrical power, $v_{c}=$ cut-in wind speed, $v_{F}=$ rated wind speed and $v_{R}=$ cut-off wind speed. 


\section{RESULTS AND DISCUSSION}

\section{A. Wind Profile Assessment}

Fig. 2 shows that there was a similar trend for the annual monthly average wind speed. Fig. 3 shows monthly average wind speeds across the years considered while June, July and August appear to be the months with the smallest amount wind supply of the site, December, January and February show the highest wind supply. It is believed to be due to seasonal changes between summer and winter. Fig. 4 indicates that there was a general constant in the values of the wind speed profiles.
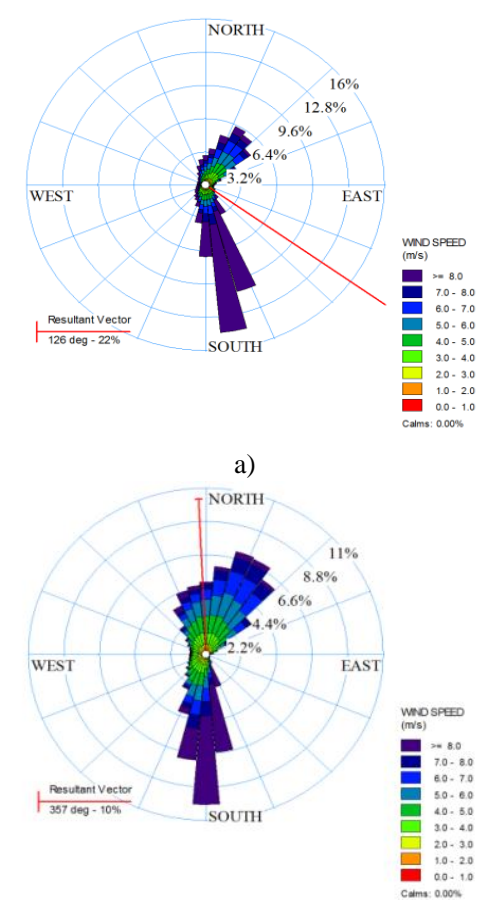

b)

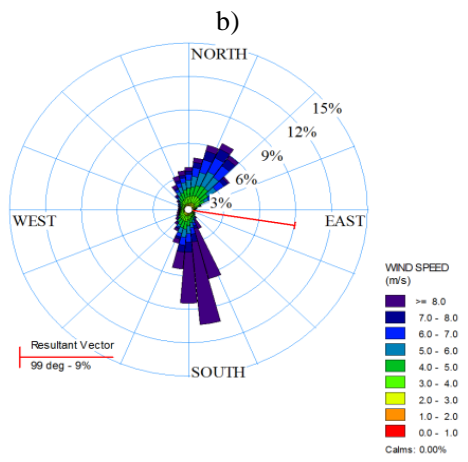

c)

Fig. 4. Prevailing wind directions; a) autumn-winter wind rose, b) spring-summer wind rose and c) whole year wind rose analysis.

The variation of monthly average wind speeds across the 34 years (Fig. 2) lay between 4.2 and $10.5 \mathrm{~m} / \mathrm{s}$ in August and December, respectively. Monthly average wind speeds across the 34 years (Fig. 3) lay between $4.99 \mathrm{~m} / \mathrm{s}$ and $7.35 \mathrm{~m} / \mathrm{s}$ in August and November, respectively. Yearly, the average measured wind speeds vary between 5.55 and $7 \mathrm{~m} / \mathrm{s}$. In addition, the period with the highest energy potential was from November to April, with November appearing to have the highest potential with value range from 3.9 to $10.5 \mathrm{~m} / \mathrm{s}$. Seasonally, the wet seasons appear to have more energy potential than the dry seasons, while the whole average for all the data was $6.33 \mathrm{~m} / \mathrm{s}$.
The above results show that the Karaburun peninsula has wind potentials that are viable for electricity generation.

Fig. 4 shows the prevailing wind directions across the months and seasons. It shows that the wind directions during spring-summer seasons do not vary differently from the autumn-winter seasons. The prevailing wind directions tend toward north-northeast (NNE) and south-southeast (SSE). Since the Karaburun peninsula is a coastal area the wind direction changes during the day.

TABLE I: ESTIMATED PARAMETERS OF WEINBULL DISTRIBUTION FOR EACH

\begin{tabular}{cccccccc}
\multicolumn{7}{c}{ YEAR OF THE WHOLE 34-YEAR PERIOD } & \\
\hline \hline & $v_{a}$ & $v_{w}$ & $k$ & $c$ & $\sigma_{a}$ & $\sigma_{w}$ & $p(v)$ \\
Years & {$[\mathrm{m} / \mathrm{s}$} & {$[\mathrm{m} / \mathrm{s}]$} & {$[-]$} & {$[\mathrm{m} / \mathrm{s}]$} & {$[\mathrm{m} / \mathrm{s}]$} & {$[\mathrm{m} / \mathrm{s}]$} & {$\left[\mathrm{w} / \mathrm{m}^{2}\right]$} \\
\hline 1981 & 6.43 & 6.22 & 1.67 & 6.97 & 3.83 & 3.83 & 282.98 \\
1982 & 5.96 & 6.45 & 1.77 & 7.24 & 4.02 & 3.75 & 291.91 \\
1983 & 6.16 & 6.00 & 1.58 & 6.68 & 3.96 & 3.87 & 272.04 \\
1984 & 6.46 & 6.19 & 1.67 & 6.93 & 4.16 & 3.82 & 278.13 \\
1985 & 6.51 & 6.54 & 1.64 & 7.31 & 4.24 & 4.09 & 335.66 \\
1986 & 6.08 & 6.11 & 1.64 & 6.83 & 4.00 & 3.83 & 273.78 \\
1987 & 6.85 & 6.88 & 1.70 & 7.71 & 4.29 & 4.17 & 373.04 \\
1988 & 6.54 & 6.57 & 1.77 & 7.38 & 3.91 & 3.82 & 309.18 \\
1989 & 5.98 & 6.02 & 1.65 & 6.73 & 3.89 & 3.74 & 259.46 \\
1990 & 6.31 & 6.33 & 1.72 & 7.10 & 3.89 & 3.79 & 286.45 \\
1991 & 6.07 & 6.11 & 1.66 & 6.83 & 3.91 & 3.77 & 268.70 \\
1992 & 6.46 & 6.50 & 1.64 & 7.26 & 4.24 & 4.08 & 328.82 \\
1993 & 5.99 & 6.02 & 1.68 & 6.74 & 3.81 & 3.68 & 253.61 \\
1994 & 6.33 & 6.36 & 1.67 & 7.12 & 4.06 & 3.92 & 301.64 \\
1995 & 6.58 & 6.60 & 1.71 & 7.40 & 4.07 & 3.99 & 327.06 \\
1996 & 6.46 & 6.50 & 1.59 & 7.24 & 4.37 & 4.19 & 342.73 \\
1997 & 6.27 & 6.31 & 1.63 & 7.05 & 4.11 & 3.97 & 303.99 \\
1998 & 6.32 & 6.35 & 1.68 & 7.11 & 3.98 & 3.89 & 297.71 \\
1999 & 6.20 & 6.23 & 1.65 & 6.96 & 3.98 & 3.87 & 286.99 \\
2000 & 6.13 & 6.15 & 1.76 & 6.91 & 3.71 & 3.62 & 255.75 \\
2001 & 6.72 & 6.74 & 1.75 & 7.57 & 4.08 & 3.98 & 338.88 \\
2002 & 6.50 & 6.53 & 1.61 & 7.29 & 4.29 & 4.15 & 342.81 \\
2003 & 5.97 & 6.01 & 1.64 & 6.71 & 3.93 & 3.77 & 259.60 \\
2004 & 6.79 & 6.82 & 1.63 & 7.62 & 4.43 & 4.30 & 383.85 \\
2005 & 6.15 & 6.17 & 1.71 & 6.92 & 3.80 & 3.71 & 267.45 \\
2006 & 5.94 & 5.97 & 1.75 & 6.70 & 3.61 & 3.53 & 234.96 \\
2007 & 6.08 & 6.11 & 1.71 & 6.84 & 3.78 & 3.68 & 258.28 \\
2008 & 6.57 & 6.60 & 1.65 & 7.38 & 4.22 & 4.09 & 342.14 \\
2009 & 6.64 & 6.68 & 1.56 & 7.43 & 4.58 & 4.37 & 382.53 \\
2010 & 6.98 & 7.02 & 1.62 & 7.84 & 4.60 & 4.45 & 422.18 \\
2011 & 5.56 & 5.58 & 1.74 & 6.26 & 3.39 & 3.31 & 193.17 \\
2012 & 6.30 & 6.33 & 1.70 & 7.10 & 3.95 & 3.83 & 291.32 \\
2014 & 6.49 & 6.53 & 1.62 & 7.29 & 4.31 & 4.13 & 339.42 \\
\hline \hline
\end{tabular}

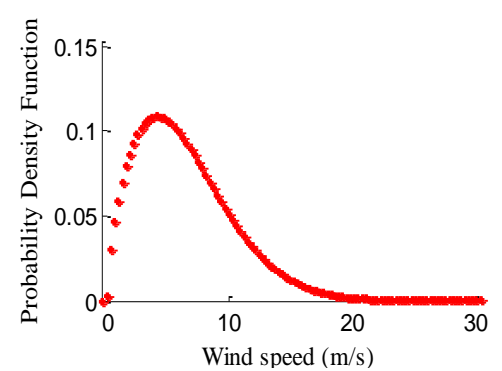

a)

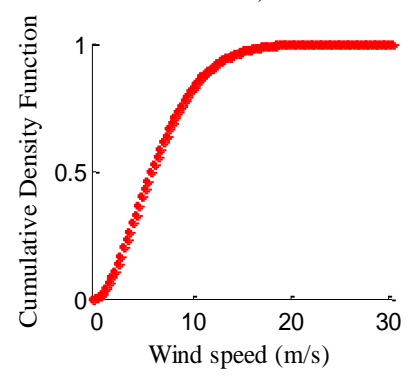

b)

Fig. 5. PDF and CDF of the whole years data series. 
The result of Weibull statistical analysis are represented in Table I, and corresponding CDF and PDF plots for the whole years data are shown in Fig. 5. The two parameters of the Weibull were found to lie between $1.56 \leq k \leq 1.77$ and $6.26 \leq$ $c \leq 7.84 \mathrm{~m} / \mathrm{s}$, respectively. Fig. 5 represents cumulative distribution of wind speed for the whole period, since for each year data series follow similar distribution pattern. Moreover,
Fig. 5 reveals that $50 \%$ of the whole data series were values up to $5.4 \mathrm{~m} / \mathrm{s}$, while $90 \%$ were values up to $12.08 \mathrm{~m} / \mathrm{s}$. Actual average wind speed were compared with Weibull mean wind speed, the coefficient of correlation was $R^{2}=0.874$.

The wind power density per unit area for the whole period was $303.65 \mathrm{~W} / \mathrm{m}^{2}$. It ranges between 422.18 and 139.17 $\mathrm{W} / \mathrm{m}^{2}$.

TABLE II: Technical Parameters of Three Types Wind Turbines, E33, G80 And E48 Together, Power Output P $P_{\text {E,ave }}$ AND CaPacity Factor CF ESTIMATED WITH WORKING UNDER WIND CONDITIONS OF THE KARABURUN PENINSULA

\begin{tabular}{|c|c|c|c|c|c|c|c|c|c|c|}
\hline \multirow[t]{2}{*}{ "Wind Turbine } & \multirow{2}{*}{$\begin{array}{c}c \\
{[\mathrm{~m} / \mathrm{s}]}\end{array}$} & \multirow{2}{*}{$\begin{array}{c}v F \\
{[\mathrm{~m} / \mathrm{s}]}\end{array}$} & \multirow{2}{*}{$\begin{array}{c}R \\
{[\mathrm{~m} / \mathrm{s}]}\end{array}$} & \multirow{2}{*}{$\begin{array}{c}P e R \\
{[\mathrm{~kW}]}\end{array}$} & \multirow{2}{*}{$\begin{array}{c}\text { Hub height } \\
{[\mathrm{m}]}\end{array}$} & \multirow{2}{*}{$\begin{array}{c}\text { Rotor diameter } \\
{[\mathrm{m}]}\end{array}$} & \multicolumn{2}{|c|}{ Pe,ave [kW] } & \multicolumn{2}{|c|}{$\begin{array}{l}C F[\%] \\
\end{array}$} \\
\hline & & & & & & & $\max$ & $\min$ & $\max$ & $\min$ \\
\hline E33 & 3 & $28-34$ & 17 & 330 & 50 & 33.4 & 78.16 & 46.04 & 23.68 & 13.95 \\
\hline G80 & 4 & 25 & 17 & 2000 & 50 & 80 & 429.63 & 240.72 & 21.48 & 12.04 \\
\hline E48 & 2 & 30 & 14 & 800 & 50 & 48 & 668.95 & 218.33 & 33.44 & 21.81 \\
\hline
\end{tabular}

\section{B. Wind Turbine Adapting and Analysis}

Installing a wind turbine is a capital decision. Therefore, it is important to match a turbine parameter to the sites wind profile [6]. Initially, this requires estimating the amount of electrical power that a real wind turbine will produce. The capacity factor is an indicator of the turbine's generation capacity [7].

We estimated performance parameters of three types of single wind turbines which were supposed to work under wind conditions of the Karaburun peninsula. In Table II there are shown main technical parameters of each technology estimated, including cut-in wind speed $v_{c}$, cut-off wind speed $v_{F}$, rated wind speed $v_{R}$, rated electrical power $P_{e R}$, hub height and rotor diameter as well two performance parameters, which are average power output $P_{e, a v e}$ and capacity factor $C F$.

Table II shows that the E48 turbine produced at the highest capacity factor with values between 21.71 and $33.44 \%$. The average wind power output ranged between 218.33 and $668.95 \mathrm{~kW}$. The G80 turbine produced at capacity factor with values between 12.04 and $21.48 \%$. The average wind power output ranged between 240.72 and $429.63 \mathrm{~kW}$. The E33 turbine produced at capacity factor with values between 13.95 and $23.68 \%$. The average wind power output ranged between 46.04 and $78.16 \mathrm{~kW}$.

\section{CONCLUSION}

An assessment of the potential of wind power generation at the Karaburun peninsula, Albania was carried out.

It was concluded that:

The Weibull probability distribution is suitable for analysis at the selected site.

Mean wind speed based on time series format for all the data was $6.33 \mathrm{~m} / \mathrm{s}$.

The Karaburun peninsula has wind potentials that are viable for electricity generation.

The wind directions during spring-summer seasons do not vary differently from the autumn-winter seasons. The prevailing wind directions tend toward north-northeast (NNE) and south-southeast (SSE). Since the Karaburun peninsula is a coastal area the wind direction changes during the day.
Two parameters of the Weibull distribution calculated using Maximum Likelihood Method which gave the best result for the selected site, varied between $1.56 \leq k \leq 1.77$ and $6.26 \leq c \leq 7.84 \mathrm{~m} / \mathrm{s}$.

Wind power density per unit area for the whole period was $303.65 \mathrm{~W} / \mathrm{m}^{2}$. It ranges between 422.18 and $139.17 \mathrm{~W} / \mathrm{m}^{2}$.

The most suitable wind turbine was E48. This turbine produced at the highest capacity factor with values between 21.71 and $33.44 \%$. The average wind power output ranged between 218.33 and $668.95 \mathrm{~kW}$.

\section{REFERENCES}

[1] E. Serdari, P. Berberi, I. Puci, and M. Halili, "Potential estimation and GHG estimation of a wind power system in Albanian South Coast," International Journal of Ecosystems and Ecology Science, vol. 3, pp. 453-458, 2015.

[2] O. B. Bilal, M. Ndongo, C. M. F. Kebe, V. Sambou, and P. A. Ndiaye, "Feasibility study of wind energy potential For electricity generation in the northwestern coast of Senegal," Energy Procedia, vol. 36, pp. 1119-1129, 2013.

[3] O. O. Ajayi, O. R. Fagbenle, J. Katende, A. S. Aasa, and O. J. Okeniyi, "Wind profile characteristics and turbine performance analysis in Kano, North-Western Nigeria," International Journal of Energy and Environmental Engineering, vol. 4, pp. 4-15, 2013.

[4] I. Fyrippis, P. Axaopoulos, and G. Panayoiotou, "Wind energy potential assessment in Naxos Island, Greece," Applied Energy, vol. 87, pp. 577-586, 2010.

[5] E. Serdari, P. Berberi, S. Miço, A. Hasanaj, and I. Puci, "Wind profile characteristics and energy potential analysis in Tirana, Albania," in Proc. AIP Conf., 2016.

[6] O. Zavalani, J. Kaçani, and P. Marango, "Renewable energy potentials of Albania," in Proc. International Conference on Renewable Energy, ICRE Damascus, Syrian Arab Republic, 2010.

[7] M. Bencherif, B. N. Brahmi, and A. Chikhaoui, "Optimum selection of wind turbines," Science Journal of Energy Engineering, vol. 2, no. 4, pp. 36-46, 2014.

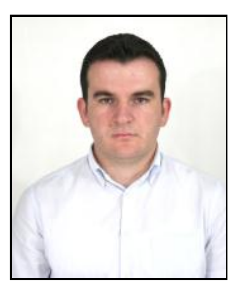

Eduart Serdari was born in Berat, Albania on August 7, 1988. He received his B.Sc and M.Sc degrees both in electrical engineering from Polytechnic University of Tirana, Tirana, Albania in 2009 and 2011 respectively. From 2011 until now, he is an lecturer at University of Vlora "Ismail Qemali", Vlora, Albania, at Faculty of Technical Science.

He is currently working toward his Ph.D. degree at Polytechnic University of Tirana, Faculty of Engineering Mathematics and Engineering Physics, Department of Physics Engineering under the supervision of Prof. Dr. Pëllumb Berberi. His fields of interest include renewable energy resources, power electronics, automatic control systems and smart grid. He is author and co-author in several professional publications. 


\section{Energy Technology}


